CZASOPISMO INŻYNIERII LA¿DOWEJ, ŚRODOWISKA I ARCHITEKTURY JOURNAL OF CIVIL ENGINEERING, ENVIRONMENT AND ARCHITECTURE

JCEEA, t. XXXIII, z. 63 (3/16), lipiec-wrzesień 2016, s. 193-200

\author{
Ewelina KRAWCZAK ${ }^{1}$ \\ Agata ZDYB ${ }^{2}$
}

\title{
ANALIZA PRACY INSTALACJI FOTOWOLTAICZNEJ W ZALEŻNOŚCI OD ORIENTACJI GEOGRAFICZNEJ
}

\begin{abstract}
Rynek odnawialnych źródeł energii z każdym dniem coraz bardziej się rozwija. Zapotrzebowanie na energię elektryczną wzrasta, przy czym zasoby konwencjonalnych i zarazem nieodnawialnych źródeł energii (paliw kopalnych) ulegają zubożeniu. Alternatywą dla nich są odnawialne źródła energii (OZE), których rezerwy uzupełniane są w naturalnych procesach ekosystemu, co stanowi o ich niewyczerpalności. Zmiany legislacyjne w Polsce dotyczące OZE spowodowały duże zainteresowanie małymi instalacjami fotowoltaicznymi w wyniku czego dotychczasowy konsument zmienia się w prosumenta energii elektrycznej. Rozwój rynku odnawialnych źródeł energii stawia przed projektantami ciągłe wyzwania, ponieważ projektowanie instalacji fotowoltaicznych o wysokiej wydajności dla istniejących budynków, przy uwzględnieniu występujących lokalnych warunków oraz architektury budowli, jest niezwykle trudne. Uzysk energetyczny systemu słonecznego zależy od wielu czynników, jednym z najważniejszych jest wartość nasłonecznienia zależna od lokalizacji (szerokości geograficznej), a także orientacja projektowanego systemu względem kierunku azymutu. Narzędziem wspomagającym i usprawniającym projektowanie instalacji PV (Photovoltaics) jest oprogramowanie DDS-CAD, pozwalające przeprowadzić symulację uzysków energii elektrycznej. Wyniki otrzymanych symulacji umożliwiają w krótkim czasie porównanie wielu wirtualnych modeli instalacji pod kątem wydajności, a co za tym idzie wybranie najkorzystniejszego wariantu dla istniejącej orientacji geograficznej. W niniejszej pracy poddane zostały analizie rezultaty symulacji wirtualnych modeli instalacji fotowoltaicznych pod względem liczby generatorów fotowoltaicznych oraz wielkości uzysku energii elektrycznej przy założeniu wykorzystania całej powierzchni dachu oraz uwzględnieniu zmiany kąta usytuowania modułów PV względem okapu połaci dachowej i kierunku azymutu.
\end{abstract}

Słowa kluczowe: fotowoltaika, energetyka słoneczna, OZE, DDS-CAD

${ }^{1}$ Autor do korespondencji / corresponding author: Ewelina Krawczak, Politechnika Lubelska, Wydział Inżynierii Środowiska, 20-618 Lublin, ul. Nadbystrzycka 38, tel. 8153845 02; e.krawczak@pollub.pl

2 Agata Zdyb, Politechnika Lubelska, Wydział Inżynierii Środowiska, 20-618 Lublin, ul. Nadbystrzycka 38, tel. 8153847 47; a.zdyb@pollub.pl 


\section{Wprowadzenie}

W ostatnich latach nastąpił intensywny rozwój fotowoltaiki na świecie, spowodowany wyczerpywaniem zasobów paliw kopalnych, wzrostem ich cen oraz uniezależnieniem się od krajów posiadających złoża kopalniane. Nie bez znaczenia są też klimatyczne konsekwencje spalania czyli emisja gazów cieplarnianych z paliw kopalnych. W wyniku wielu zmian legislacyjnych, jak również zgodnie z europejską strategią Unii Energetycznej oraz z Dyrektywą Parlamentu Europejskiego i Rady 2012/27/UE z dnia 25 października 2012 r. w sprawie efektywności energetycznej Polska do 2020 r. powinna uzyskać $15 \%$ udziału OZE w produkcji energii. Przyjęte na szczycie Unii Europejskiej w październiku 2014 r. nowe ramy klimatyczno-energetyczne zakładają kolejne, wieloletnie działania zapobiegające zmianom klimatu poprzez redukcję emisji dwutlenku węgla, a także zwiększenie udziału energii pochodzącej ze źródeł odnawialnych. Kraje członkowskie UE muszą dążyć do poprawy efektywności energetycznej o $27 \%$ do roku 2030. Zgodnie z danymi pochodzącymi z Urzędu Regulacji Energetyki zainstalowana moc w polskich elektrowniach wytwarzających energię elektryczną z promieniowania słonecznego wynosi 87,718 MW (stan z dnia 31.03.2016 r.). Do roku 2016 zostało zgłoszonych w Polsce 267 elektrowni wytwarzających energię z promieniowania słonecznego i około 3 tysięcy mikroinstalacji, w tym w 2015 r. - 2,1 tysiąca instalacji (systemy on-grid) [1].

Zachodzące zmiany na rynku energetycznym motywują dotychczasowego konsumenta, aby stał się prosumentem energii elektrycznej [2]. Prosument może całkowicie uniezależnić się od dostawcy energii elektrycznej konsumując energię, którą sam wytworzy w systemie autonomicznym (off-grid). Drugim typem instalacji prosumenckich najczęściej instalowanych na dachach budynków wolnostojących są systemy on-grid (rys.1) współpracujące z siecią przesyłową [3].

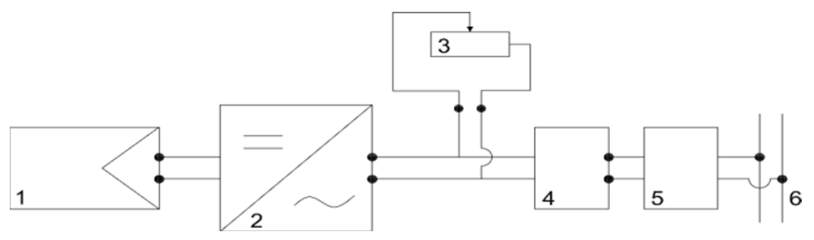

Rys. 1 Schemat instalacji prosumenckiej: 1-moduły fotowoltaiczne, 2-falownik, 3-obciążenie pochodzące z urządzeń elektrycznych, 4-urządzenie służące do pomiaru energii elektrycznej oddawanej do sieci energetycznej, 5-urzadzenie służące do pomiaru energii elektrycznej kupowanej z sieci, 6-podłączenie do sieci przesyłowej

Fig. 1 Schematic diagram of the prosumer photovoltaic system: 1-PV modules, 2-inverter, 3-load, 4-electricity meter for production, 5- electricity meter for consumption, 6-utility grid

Instalacje on-grid samoczynnie sterują eksportem i importem wytworzonej energii, dlatego są to układy niezawodne. Jeżeli uzysk przewyższa zapotrzebowanie energetyczne gospodarstwa domowego, to nadwyżka energii sprzedawana jest do sieci elektroenergetycznej, w przypadku niedoboru istnieje możliwość dokupienia jej od lokalnego dystrybutora [4]. W systemie przyłączonym do sieci 
przesyłowej można wyróżnić część stałoprądową DC, w której energia elektryczna dostarczana jest w postaci prądu stałego. W skład części DC wchodzi: moduł PV, przewody, skrzynki rozdzielcze oraz konstrukcje nośne. Kolejną częścią jest zmiennoprądowa AC, w której energia dostarczana jest za pomocą prądu przemiennego, zawierająca następujące elementy: falowniki, przewody, elementy ochronne i urządzenia pomiarowe.

W Polsce brakuje wyraźnego wsparcia inwestycji w fotowoltaikę pomimo rosnącego zainteresowania systemami PV [5]. Niezbędna jest długookresowa strategia rozwoju wspierająca indywidulanych konsumentów energii elektrycznej poprzez wprowadzenie różnych systemów wsparcia inwestycyjnego [6]. Jednym z nich jest program PROSUMENT realizowany przez NFOŚiGW, który wspiera zakup i montaż mikroinstalcji przyjaznych środowisku, a także dba o podniesienie świadomości ekologicznej Polaków. Istnieją dwie możliwości wsparcia potencjalnych prosumentów: przy pomocy bezzwrotnego dofinansowania 40\% kosztów kwalifikowanych (w latach 2014-2016), 30\% od roku 2016 lub za pomocą taryfy gwarantowanej FIT. Mechanizm wsparcia FIT zapewnia beneficjentowi programu stałą stawkę energii $0.75 \mathrm{zt} / \mathrm{kWh}$ dla instalacji do $3 \mathrm{~kW}$ oraz $0.65 \mathrm{zt} / \mathrm{kWh}$ dla instalacji od 3 do $10 \mathrm{kWh}$.

Wydajność energetyczna instalacji fotowoltaicznej zależy od wielu czynników [7-8]. Jednym z najważniejszych jest ilość promieniowania słonecznego padającego na powierzchnię modułów, co z kolei zależne jest od lokalnych warunków pogodowych. Określenie potencjału energii promieniowania słonecznego jest kluczowe dla prognozy uzysku energii z instalacji słonecznej [9]. Polska posiada porównywalne warunki klimatyczne jak Niemcy, obecny lider technologii OZE, który w maju 2016 r. po raz pierwszy w historii zapewnił całodzienne pokrycie zapotrzebowania energetycznego $\mathrm{w}$ państwie energią $\mathrm{z}$ odnawialnych źródeł. Położenie geograficzne instalacji (długość i szerokość geograficzna) wraz z indywidualnymi cechami systemu, takimi jak orientacja względem azymutu czy też kąt pochylenia modułów determinują uzysk energetyczny oraz wydajność pracy systemu. Najkorzystniejsze jest usytuowanie modułów pod kątem $35^{0}$ względem poziomu (w naszej szerokości geograficznej) i zwrócenie ich na południe (azymut $0^{0}$ ). Połacie dachowe w istniejących domach mają jednak różne kąty nachylenia oraz różną orientację azymutu. W celu uzyskania maksymalnej energii należy rozważać ułożenie modułów w różnych konfiguracjach. $\mathrm{W}$ przedstawionej pracy porównane są dwa warianty rozmieszczenia modułów, dla których produkcja energii zmienia się wraz ze zmianą azymutu.

\section{Metodyka}

Dane dotyczące uzysku energetycznego, które zostały przeanalizowane w dalszej części pracy pochodzą z oprogramowania DDS-CAD, wersja 11, które jest narzędziem wspomagającym projektowanie, pozwalającym projektować instalacje fotowoltaiczne dowolnie zintegrowane z budynkiem, jak również sys- 
temy naziemne. Dzięki zaimplementowanym do programu DDS-CAD modułom (sanitarno-grzewczy, wentylacyjno - klimatyzacyjny, elektrotechniczny oraz fotowoltaiczny) możliwe jest tworzenie wielobranżowych, kompleksowych opracowań. Każdy moduł dedykowany jest inżynierom innej branży, co pozwala na tworzenie indywidualnej instalacji będącej integralną częścią opracowywanego modelu. Występujący w programie moduł architektoniczny, współpracujący z każdym z pozostałych komponentów, pozwala na stworzenie dwuwymiarowego oraz trójwymiarowego modelu budynku. Prototyp konstrukcji tworzony jest na podstawie dwuwymiarowych podkładów architektonicznych stworzonych w innych programach grafiki inżynierskiej (np. *.dwg, *.jpg czy *.pdf). Wykorzystana nowoczesna technologia BIM (Building Information Modeling) dodatkowo usprawnia i intensyfikuje pracę. Jest to narzędzie odwzorowujące fizyczne i funkcjonalne właściwości tworzonego projektu. Posługiwanie się wirtualnym modelem umożliwia uzyskanie pełnej dokumentacji projektowej - części rysunkowej oraz obliczeniowej, analizy ekonomicznej, czy też zestawienia materiałów. Program ten wyróżnia się nowatorską technologią pozwalającą na wyeliminowanie możliwych błędów, kolizji oraz na wirtualne sprawdzenie wszystkich aspektów planowanej konstrukcji, instalacji już na etapie projektowania, jak również wykonanie analizy nasłonecznienia instalacji PV. Powstający model jest wirtualnym odwzorowaniem rzeczywistych elementów budynku oraz instalacji w standardzie zorientowanym obiektowo, co optymalizuje proces projektowania, wykonania, a także zakończenia inwestycji.

\section{Wyniki i analiza}

W celu sprawdzenia zmiany uzysku energetycznego w zależności od zmiany orientacji geograficznej analizie poddano instalację fotowoltaiczną o mocy 4,8 kWp zintegrowaną z dachem budynku jednorodzinnego dwukondygnacyjnego o łącznej powierzchni $150 \mathrm{~m}^{2}$. Inwestycję przewidziano $\mathrm{w}$ miejscowości Warszawa w województwie mazowieckim w III strefie klimatycznej. Budynek zaprojektowany jest do zamieszkania przez 5 osób. Do obliczeń uzysku energetycznego przyjęto dane klimatyczne pobrane z oprogramowania Meteonorm 7, zintegrowanego z programem DDS-CAD.

Przewidziano dwie konfiguracje rozmieszczenia modułów (rys. 2) oraz dwa warianty obliczeniowe instalacji słonecznej. W pierwszej konfiguracji założono wykorzystanie prostokątnej części trapezowatej powierzchni połaci dachu. Część zadaszenia nie została uwzględniona w symulacji, z uwagi na ustandaryzowanie kształtu przykrycia dachowego. Zaprojektowano system zbudowany z 24 sztuk modułów polikrystalicznych firmy Solar EnerTech (Shanghai) Co., typ SE200 54P o mocy nominalnej $200 \mathrm{~W}$. Powierzchnia modułu wynosi $1,494 \mathrm{~m}^{2}$, sprawność $14 \%$. Przewidziano montaż instalacji na połaci dachowej zorientowanej w kierunku południowym o wymiarach $8,7 \mathrm{~m} \times 5,5 \mathrm{~m}$, powierzchni $47,85 \mathrm{~m}^{2}$ oraz kącie nachylenia $23,6^{0}$. W wariancie I zbadano zmiany 


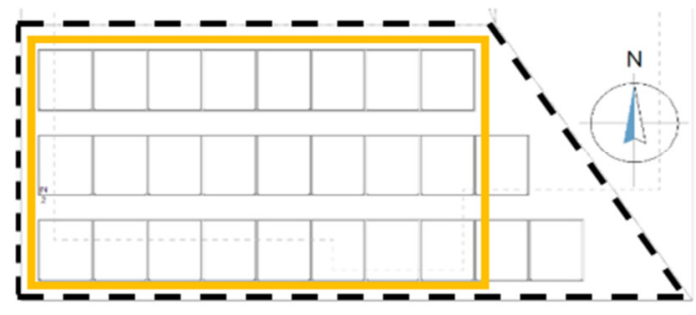

Rys. 2 Konfiguracje instalacji fotowoltaicznej, linia ciągła - konfiguracja I, linia przerywana -konfiguracja II

Fig. 2 Configurations of PV installation, solid line configuration I, dotted line - configuration II

uzysku energetycznego przy zmianie azymutu. Symulacje uzysku energii elektrycznej zostały wykonane w krokach, co piętnaście stopni zmian azymutu.

Moduły zostały rozmieszczone w trzech rzędach po 8 sztuk zachowując niezbędne odstępy montażowe oraz nachylenie $12,4^{0}$ do połaci dachowej (wartość inklinacji $-36^{0}$ ). Odsunięcie od siebie kolejnych rzędów instalacji zapewnia uniknięcia zacienienia.

Drugi wariant obliczeniowy zakłada zmianę azymutu z jednoczesną zmianą kąta skierowania modułów fotowoltaicznych, tak aby moduły zainstalowane na dodatkowych stelażach były zawsze zwrócone na południe. Zachowano kąt pochylenia modułów względem połaci dachowej. Przy założeniu wykorzystania całej powierzchni dachu w pierwszej konfiguracji obliczeniowej liczba modułów PV jest stała i wynosi 24 sztuki. Przy zmianie azymutu powstający za generatorami cień zwiększa się, obligując jednocześnie do wydłużenia odległości pomiędzy kolejnymi rzędami paneli. Powoduje to spadek ilości paneli do 17 sztuk (rys. 3a). $\mathrm{Na}$ rysunku $3 \mathrm{~b}$ przedstawiono uzysk energetyczny wygenerowany na podstawie symulacji pracy instalacji fotowoltaicznej. W obu wariantach obliczeniowych najkorzystniejszy uzysk energetyczny wynosi $3740,86 \mathrm{kWh} /$ a przy azymucie $0^{0}$.

a)

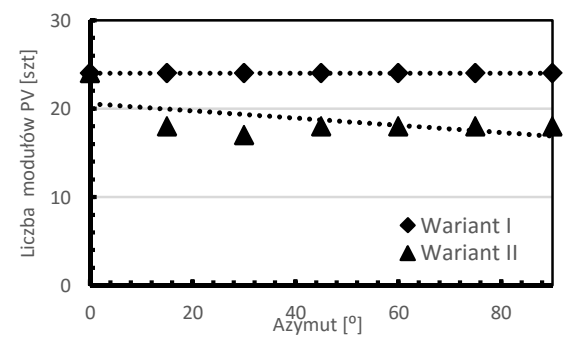

b)

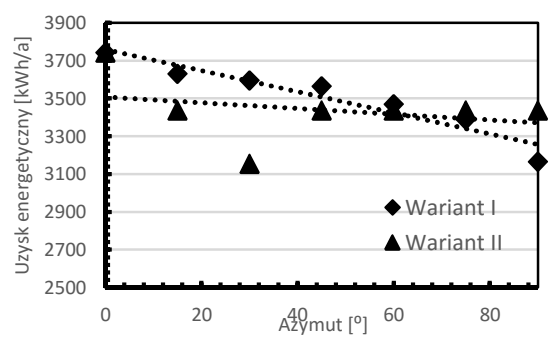

Rys. 3 a) Zależność liczby modułów PV od kierunku azymutu, b) Zależność uzysku energetycznego od kierunku azymutu

Fig. 3 a) Dependence of quantity of PV modules on the azimuth, b) Dependence of energy yield of $\mathrm{PV}$ modules on the azimuth 
Spadek ilości wytwarzanej energii pomiędzy azymutem $0^{\circ}$ i $90^{\circ}$ dla pierwszego wariantu obliczeniowego wynosi $577,15 \mathrm{kWh} / \mathrm{a}$, dla drugiego $305,49 \mathrm{kWh} / \mathrm{a}$. Współczynnik uzysku energetycznego dla instalacji w wariancie I wynosi $6,41 \mathrm{kWh}$ przy zmianie azymutu o $1^{0} \mathrm{w}$ stosunku rocznym, w wariancie II - $9,64 \mathrm{kWh} / \mathrm{a} /{ }^{0}$.

W drugiej konfiguracji (rys. 2) przeanalizowano pracę instalacji fotowoltaicznej przy założeniu wykorzystania całej powierzchni połaci dachowej, o kształcie trapezu prostokątnego. Powierzchnia przeznaczona pod montaż instalacji fotowoltaicznej wynosi $57,75 \mathrm{~m}^{2}$. Założono takie same warianty obliczeniowe jak w konfiguracji pierwszej. Na rysunku 4a przedstawiono liczbę modułów fotowoltaicznych w zależności od azymutu. W przypadku zmiany azymutu ilość ta jest stała (27 sztuk), natomiast przy jednoczesnej zmianie kąta położenia instalacji względem okapu połaci dachowej liczba modułów ulega zmianie w zakresie 15-27 sztuk. W przypadku niestandardowych kształtów połaci dachowej, to właśnie jej forma jednoznacznie determinuje wielkość instalacji. Wartość uzysku energetycznego (rys. 4b) dla kierunku azymutu najbardziej i najmniej korzystnego dla pierwszego wariantu obliczeniowego wynosi $459,81 \mathrm{kWh} / \mathrm{a}$, natomiast dla drugiego $1980,41 \mathrm{kWh} / \mathrm{a}$. Tak znaczna różnica uzysku energii (wariant II) spowodowana jest dużą rozbieżnością pomiędzy kątem krawędzi połaci oraz kierunku azymutu. Różnica uzysków energetycznych pomiędzy wariantami spowodowana jest przede wszystkim zmianą ilość modułów PV, których liczba zależy od występującej pomiędzy nimi strefy zacienienia, a także specyficznej konstrukcji więźby dachowej. Kluczowe znaczenie ma krawędź połaci dachowej poprowadzonej pod niestandardowym kątem. Gdy kąt krawędzi połaci pokrywa się z kątem posadowienia paneli to możliwe jest wykorzystanie prawie całej powierzchni tej części dachu. W momencie, gdy te dwa kąty nie współgrają ze sobą zostaje niewykorzystane nawet do $20 \%$ powierzchni połaci dachowej.
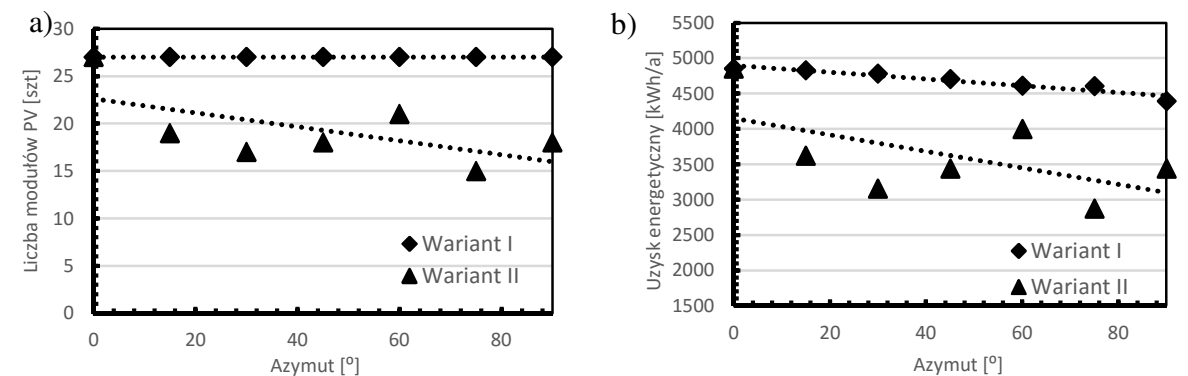

Rys. 4 a) Zależność liczby modułów PV od kierunku azymutu, b) Zależność uzysku energetycznego od kierunku azymutu

Fig. 4 a) Dependence of quantity of PV modules on the azimuth, b) Dependence of energy yield of PV modules on the azimuth 


\section{Podsumowanie}

Ilość produkowanej energii elektrycznej jest ściśle związana z położeniem modułów fotowoltaicznych względem azymutu. Jest to czynnik determinujący wydajność pracy systemu słonecznego, niezależnie od technologii wykonania budujących go ogniw fotowoltaicznych. W przypadku istniejącego budynku należy zadecydować, jaki sposób montażu instalacji sprawdzi się najlepiej, wykorzystujący całą powierzchnię połaci dachowej czy montując moduły PV zgodnie z kierunkiem azymutu. Zależy to przede wszystkim od indywidualnej konstrukcji więźby dachowej, kształtu poszczególnych połaci oraz możliwości wykorzystania jak największej powierzchni, pomimo zmiany kąta usytuowania modułów PV względem okapu połaci dachowej. W przypadku montażu modułów na prostokątnej połaci zorientowanej w zakresie $0-60^{\circ} \mathrm{w}$ stosunku do azymutu korzystniejsze uzyski energetyczne występują przy całkowitym wykorzystaniu jej powierzchni. W przypadku odchylenia o kąt $75-90^{\circ}$ wariant zakładający, iż moduły są zawsze zwrócone na południe uzyskuje o 8\% lepsze rezultaty. Przy wykorzystaniu całej powierzchni połaci (niezależnie od kształtu), w obu wariantach następuje spadek generowanej energii odpowiednio o 15\% i 40\%. Uwzględniając otrzymane wyniki ze wszystkich rozpatrywanych wariantów należy zauważyć, iż największy uzysk energetyczny generuje system fotowoltaiczny wykorzystujący całą powierzchnię dachu (nawet przy niestandardowym kształcie połaci) niezależnie od odchylenia od kierunku azymutu. Inżynier przed rozpoczęciem procesu projektowania musi rozważyć obie konfiguracje uwzględniając konstrukcję dachu istniejącego budynku. Dzięki wykorzystaniu symulacji komputerowych tworzonych m.in. w programie DDS-CAD, możliwe jest sprawdzenie wielu wariantów obliczeniowych i zrealizowanie inwestycji najefektywniejszej energetycznie.

\section{Literatura}

[1] Pietruszko S.: Fotowoltaika - przyszłość bezpieczeństwa energetycznego, Warunki Techniczne $1 \mathrm{nr} 12$ 2016, s. 26-29.

[2] Olchowik J. M., Cieslak K., Gulkowski S., Mucha J., Sordyl M., Zabielski K., Szymczuk D., Zdyb A.: Progress of development of PV systems in south-eastern Poland, Proc. of 35th IEEE PVSC Honolulu, Hawaii, 20-25 June 2010, p. 002397002399.

[3] Stryczewska D.: Energie odnawialne. Przegląd technologii i zastosowań, Wydawnictwo Politechniki Lubelskiej, Lublin 2012.

[4] Klugmann-Radziemska E.: Fotowoltaika w teorii i praktyce, Wydawnictwo BTC, Legionowo 2010.

[5] Olchowik J. M., Dragan P., Gembarzewski O., Gulkowski S., Szymczuk D., Tomaszewski R.: The reasons of the delays in introducing in Poland law regulations favorable for photovoltaics. Procedings of the $28^{\text {th }}$ EU PVSEC, Paris, France, 2013, p. 4676-4679. 
[6] Olchowik J. M., Cieslak K., Gulkowski S., Mucha J., Sordyl M., Zabielski K., Szymczuk D., Zdyb A.: Activation of polish public administration bodies and business within the IEE PVS in Bloom Project, Proc. of 26th European Photovoltaic Solar Energy Conference and Exhibition, Hamburg, Germany, October 2011, p. 4693-4696.

[7] Krawczak E., Gułkowski S., Olchowik J.M.: Badanie efektywności pracy fotowoltaicznego systemu ,off-grid” w warunkach zimowo-wiosennych dla Lubelszczyzny, Czasopismo Inżynierii Lądowej, Środowiska i Architektury - Journal of Civil Engineering, Environment and Architecture, JCEEA, t. XXXI, z. 61 (3/II/14), 2014, s. 317-328, DOI:10.7862/rb.2014.98.

[8] Mroziński A.: Badanie efektywności energetycznej laboratoryjnej instalacji fotowoltaicznej, Czasopismo Inżynierii Lądowej, Środowiska i Architektury - Journal of Civil Engineering, Environment and Architecture, JCEEA, t. XXXI, z. 61 (3/II/14), 2014, s. 357-366, DOI:10.7862/rb.2014.102.

[9] Siuta-Olcha A.: Potencjał energii promieniowania słonecznego w województwie lubelskim. Zeszyty Naukowe Politechniki Rzeszowskiej $\mathrm{Nr}$ 283, Budownictwo i Inżynieria Środowiska z. 59 (2/2012/II), 2012, s. 693-698.

\section{ANALYSIS OF PHOTOVOLTAIC INSTALLATION WORK ACCORDING TO GEOGRAPHICAL ORIENTATION}

\section{S u m m a r y}

The market of a renewable energy sources is still developing. Electricity demand is increasing and fossil fuels are being depleted. The alternative for them are renewable energy sources, their reserves are replenished in the natural ecosystem processes, which proves the fact of their being unexhausted. Legislative changes in Poland caused a big interest in small photovoltaic installations, and consequently the energy consumer may become electricity prosumer. Market development of renewable energy sources challenges designers continuously because designing the high efficiency photovoltaic systems for existing buildings, taking into account local conditions and existing buildings architecture, is extremely difficult. The yield of solar energy system depends on many factors. One of the most important is the value of solar radiation depending on the location (geographical latitude), as well as the orientation of the designed system with respect to the azimuth. Supportive and labor-saving computer software for design PV systems is DDS-CAD, which allows to simulate electricity yield. The results of simulation allows for quick comparison of various virtual models of installations taking into account their efficiency and quick select of the most advantageous variant according to geographical orientation. In this paper, the results of virtual simulation models of photovoltaic systems in terms of the number of PV generators and the size of the energy yield have been analyzed. The analysis was conducted assuming the use of wholesurface roof and taking into account changes in the angle of PV modules placement in relation to the eaves of the roof slope and azimuth direction.

Keywords: photovoltaics, solar energy, renewable energy, DDS-CAD

DOI:10.7862/rb.2016.201

Przestano do redakcji: 25.05.2016 $r$.

Przyjęto do druku: 30.11.2016 r. 